\title{
Ultrastructural Study During Feeding and Mating on the Genital System in Female Tick Hyalomma (Hyalomma) anatolicum anatolicum (Ixodoidea: Ixodidae)
}

\author{
Faisal A. Bughdadi \\ Teacher College, Makkah, Department of Biology
}

\begin{abstract}
The fine structure of genital system in the female Hyalomma (Hyalomma) anatolicum anatolicum is described during feeding and mating. Feeding initiates oocytes growth through the previtellogenic. Oogenesis is induced by feeding. Growing oocytes secreate dense granules into the cytoplasm and form surface microvilli. The cytoplasm has associated dense vesicles, Golgi bodies, rough endoplasmic reticulum and multivesicular bodies.
\end{abstract}

The vagina, consisting of vestibular (VV) and cervical (CV) regions, is formed of an epithelium lined internally with a folded cuticular layer and surrounded externally by muscle layers. These facilitate the passage of endospermatophres containing sperms into the receptaculum seminis (RS), and ova to the exterior. A pair of tubular accessory glands (AG) opening at the junction of VV and CV consist of an epithelial layer of undifferentiated cells. As feeding progresses, these cells synthesise their granular secretion that functions to lubricate the egg surface during its passage through VV. The receptaculum seminis consists of cuboidal cells lined with a cuticular layer. These cells appear rich with glycogen and lipid vacuoles, may act as source of energy required for various cell activities including granule synthesis and exocytosis. The granules discharge their contents into intercellular spaces distributed throughout the wall of the receptaculum seminis, and communicate with the main lumen via narrow channels. No secretory activity has been observed during and after feeding in the connecting tube. At and during final stage of feeding, the cell cytoplasm contains large, phagosomal vacuoles penetrated by sperms, in addition to micropinocytotic vesicles which serve to break down the seminal fluid and other material. The oviducal secretion may function as a tanning agent to harden the egg shell and also probably act as a lubricant at the state of egg passage. In addition, the basal membrane is infolded giving characteristic features of epithelia involved in ion water transport.

Keywords: Ixodid tick Genital tract, electron microscope. 


\section{Introduction}

Ticks are obligate ectoparasites which infest every major vertebrate animal group, including man, and feed on their blood. They are reservoirs and vectors of numerous pathogenic viruses, rickettsia, bacteria, protozoa and filaria ${ }^{[1]}$.

Ixodid ticks are highly specialised bloodsucking arthropods. The tick is known to be one of the important reservoir and vectors of microorganisms causing diseases to livestock and wild life ${ }^{[2]}$. The ticks have the ability to transmit certain pathogens to their progeny via transstadial and transovarial infection ${ }^{[3]}$.

Hyalomma (H) anatolicum anatolicum is common in Saudi Arabia wherever the camels occur. It is very important ectoparasite which infests the majority of camels and can also feed on humans.

The anatomy and histology of the female reproductive organs have been investigated in several ixodids ${ }^{[2],[4-7]}$ and $\operatorname{argasids}^{[8,9]}$.

The ultrastructure of the developing oocytes has been described in the ixodid ticks Rhipicephalus bursa ${ }^{[10]}$, Dermecentor andersoni ${ }^{[11]}$, Hyalomma asiticum ${ }^{[12] ;[13]}$, Amblyomma hebraeum ${ }^{[10] ;[12]}$ and Hyalomma anatolicum $^{[7]}$. The general pattern is the same in each of these species. Juliana et $a l^{[15]}$. showed that the ovary of the tick amblyomma triste is classified as panoistic, which is characterized by the presence of oogonia without nurse and follicular cells.

Brinton $e t a l^{[16]}$. have described the fine structure of the oviducts in relation to spermiogenesis in the oxidid ticks Dermacentor andersoni, and Raikhel ${ }^{[17]}$ has studied briefly the effect of blood meal and mating on the reproductive system in Hyalomma asiaticum. El-Shoura ${ }^{[18]}$ described the structure of female genital organs, including the egg waxing apparatus, the Gene's organs, in unfed $O$. erraticus. The fine structure and mechanism of the Gene's organs in feeding and ovipositing $H$. dromedrii was also revealed by El-Shoura ${ }^{[19]}$. El-Shoura et al. ${ }^{[20]}$ described that certain genital organs in the nuttalliellid tick, Nuttalliella namaqua, combine features of argaside and ixodid ticks.

The female genital organs of the tetrablemmid Indicoblemma lannaianum are astonishingly complex ${ }^{[21]}$. The copulatory orifice lies anterior to the opening of the uterus externus and leads into a narrow 
insertion duct that ends in a genital cavity. The genital cavity continues laterally in paired tube-like copulatory ducts, which lead into paired, large, sac-like receptacula ${ }^{[21]}$.

\section{The Present Study}

The present study describes the ultrastructure of the female genital organs in the tick Hyalomma (Hyalomma) anatolicum anatolicum during feeding and mating, and up to oviposition to establish a basis for additional future research incorporating biochemical and cytochemical approaches to increase our knowledge of chemotactic processes influencing sperm.

\section{Materials and Methods}

The specimens of Hyalomma $(H)$ anatolicum anatolicum used in this study were collected mainly from abattoirs and camel markets at Jeddah and Makkah in Saudi Arabia, particularly the Muna and Arafat areas and maintained at $28{ }^{\circ} \mathrm{C}$ and $75 \%$ relative humidity. Domesticated rabbits were used as laboratory hosts. Unfed (7-day-old), feeding (3, 5 and 7 days after attachment), Fully engorged (3, 5 and 7 days after detachment), and ovipositing females were dissected in insect physiological saline. The genital system was released from surrounding connective tissues and separated into organs, each of which was fixed individually in 3\% glutaraldehyde in Na-cacodylate buffer $(\mathrm{pH} 7.2)$, postfixed in an alcohol series and embedded in Spurr resin ${ }^{[22]}$. Semithin sections were stained with $1 \%$ toluidine blue. For transmission electron microscopy (TEM) ultrathin sections were double-stained with uranyl acetate and lead citrate and examined under a Philips 400 TEM. Images were recorded on Ilford E.M cut film and printed on Ilfospeed multigrade paper. (More details in Bughdadi ${ }^{[23,24]}$.

\section{Results}

\section{Ovary}

The blood meal and mating initiates the resumption of oogenesis. The ovary starts to increase in both length and diameter. It thus enters the great cytoplasmic growth phase (stage II). This increase in size is due to 
the differentiation of most of the oogonia to primary oocytes; to the enlargement of already existing primary oocytes and to the protrusion of the oocytes from the ovary into the body cavity. As the oocytes increase in size, these connecting (funicle) cells become columnar and, with the oocytes, extend into the body cavity (Fig. 1), carrying their connective tissue sheath, or tunica propria, before them (Fig, 2).

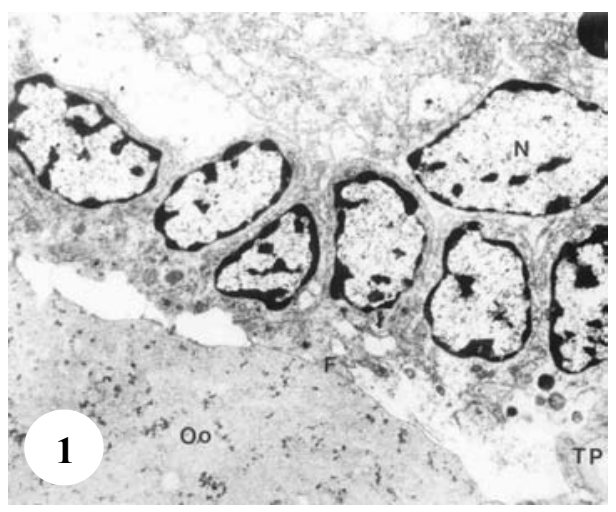

Fig. 1. Transverse section showing the funicle cells (F) which connect the oocyte (Oo) with the ovarian wall. Note tunica propria (TP). X $\mathbf{1 5 , 0 0 0 .}$

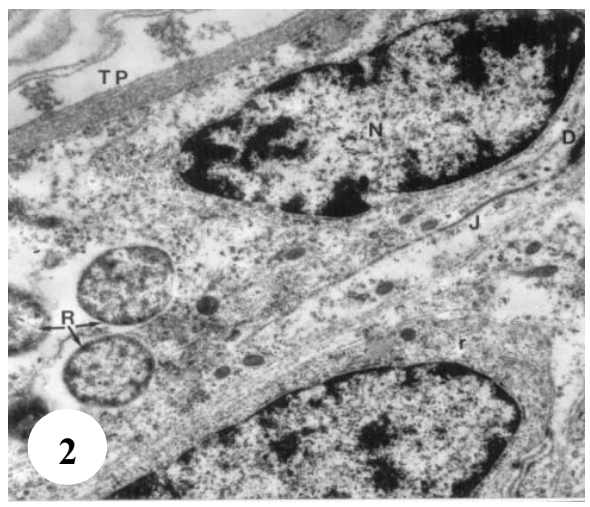

Fig. 2. Transverse section showing the funicle cells containing rickettsialike microogranisms (R), desmosome (D), junction complex $(J)$, free ribosomes (r), and connective tissue sheath of tunica propria (TP). X 7,000 .

The oocytes cell cytoplasm is rich in free ribosomes, membranebounded electron-lucent vacuoles, numerous small mitochondria, lipid droplets, and single rickettsia - like microorganisms (Fig. 3, 4). Micropinocytotic coated pits appear in the oocytes cell membrane between the bases of the microvilli (Fig. 4). The adjacent finical cells are joined by long, tortuous desmosomes, junctional complexes and numerous mature spermatozoa are observed in the ovarian lumen (Fig. 5,6). The oocytes show further development changes. Further changes in the nucleus; the beginning of cytoplasmic changes, including those associated with primary yolk granules formation (vitellogenesis) and early stages in the formation of egg shell (vitelline envelope). 


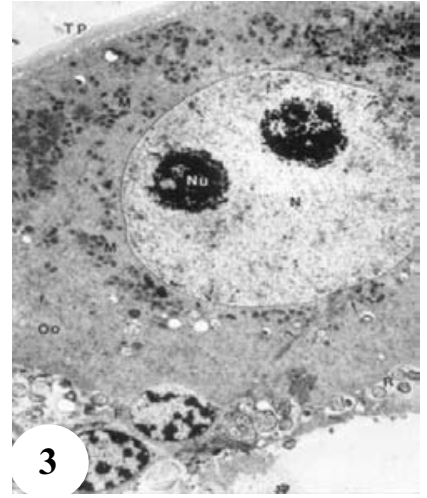

Fig. 3. Part of oocyte (Oo), showing nucleus (N), two nucleoli $(\mathbf{N u})$, mitochondria (M), ribosomes (r), fine granular euchromatin stars) in the nucleoplasm, ribosomal - like granules close to the nuclear evelope and in the cytoplasm (arrows). Note the rickettsia-like microorganisms (R) and part of funicle cells (F). X 6,000.

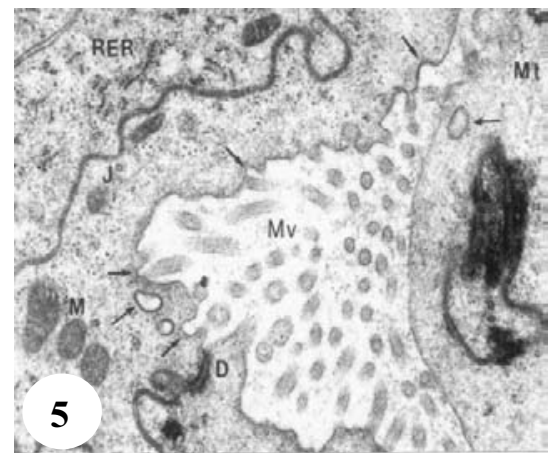

Fig. 5. Funicle cells containing free ribosomes (r), mitochondria (M), microtubles (Mt), rough ER (RER). The apical microvilli (Mv) project into the ovarian lumen and are coated with glycocalyx. Note also coated vesicles and pits (arrows), junction (J), desmosome (D). $\mathrm{X}$ 37,500 .

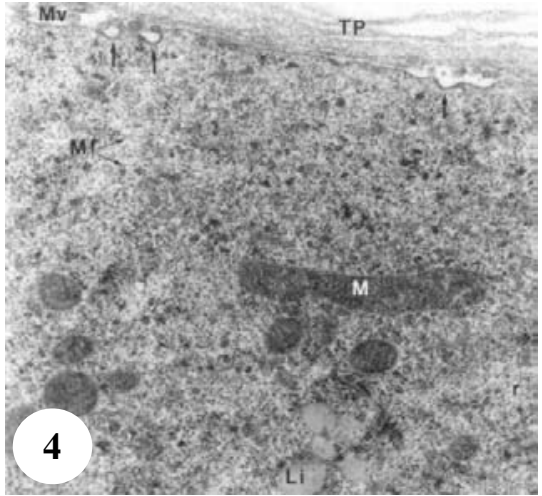

Fig. 4. Cytoplasm showing mitochondria (M), lipid droplets (Li), free ribosomes $(r)$, and microfilamentous material (Mf). Note the microvilli (Mv) on the surface of the oocyte underlying the tunica propria (TP) and the coated pits arrows). $X$ 16,500 .

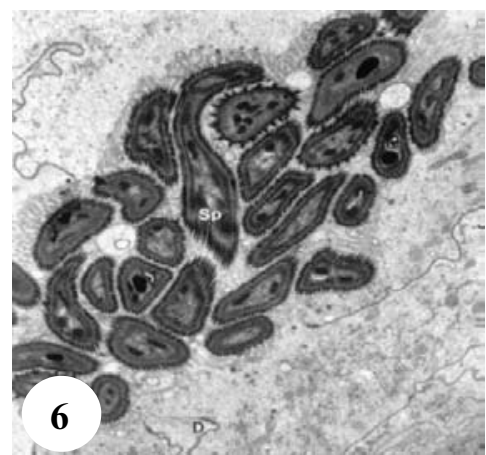

Fig. 6. Section showing funicle cells surrounding numerous mature sperms (Sp) in the ovarian lumen. Note the junctions (J) and desmosomes (D). X 12,500.

In the ooplasm, large patches of condensed and loose electrondense ribosomal aggregates are in close association with the nuclear envelope (Fig. 3, 7). Single rickettsia-like microorganisms are also present in the cytoplasm (Fig. 7). 


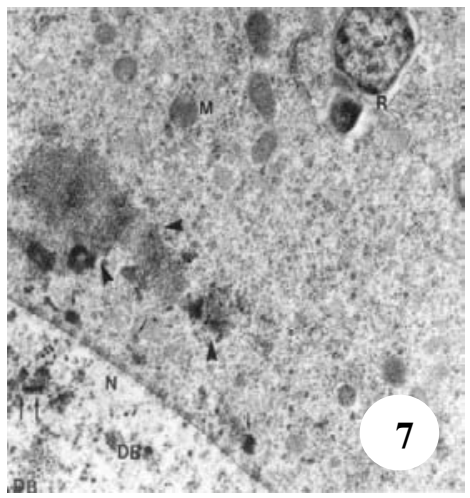

Fig. 7. Part of cytoplasm and nucleus $(\mathrm{N})$ with ribosomal-like granules in the nucleoplasm and in the cytoplasm near the nuclear envelope (arrows), mitochondria (M), rickettsia-like microorganisms ( $R$ ), granular-ribosomal aggregates arrowheads) and dense bodies (DB). $\mathrm{X} \mathbf{7 , 4 0 0}$.

\section{Vagina}

During feeding, the entire genital system enlarges gradually in size during feeding and mating (attachment), and rapidly after the tick detachment to reach its maximum growth during oviposition. However, no remarkable structural changes were observed in both VV and CV during feeding (Fig.8). During oviposition, VV cuticular folds become considerably unfolded due to the enormous stretching of the entire cuticular lining, which in some areas appear lamellate. Degenerated epithelial cells of $\mathrm{CV}$, as those of $\mathrm{VV}$, are electron-dense with pycnotic nuclei (Fig. 9).



Fig. 8. Semithin sections of vestibular vagina (VV) and cervical vagina (CV)during feeding. $X 1,200$.



Fig. 9. Degenerated epithelial cells of cervical vagina (CV) showing pycnotic nucleus $(\mathrm{N})$. cu, cuticular lining. X 4000. 


\section{Tubular Accessory Glands}

As feeding progresses, the glandular epithelial cells become pyramidal with many ultrastructural features indicating secretory activity. The cytoplasm becomes packed with well-developed rough endoplasmic reticulum (RER) which is apparently responsible for the formation of electron-dense granules distribution throughout the cytoplasm (Fig. 10). The cell apices containing secretory granules and mitochondria project numerous, elongated, contiguous microvilli enclosing peripheral, longitudinally oriented fibrillar material within their cortex (Fig. 11). Some pinocytoticpits are detected in the apical cell membrane (Fig. 11). The cell basal region is infolded (Fig. 12). The nuclei are greatly enlarged and located basally; their chromatin consistency becomes loose and the dense clump, seen in unfed ticks, is remarkably decreased; the nucleolus granular components are abundant (Fig. 12).

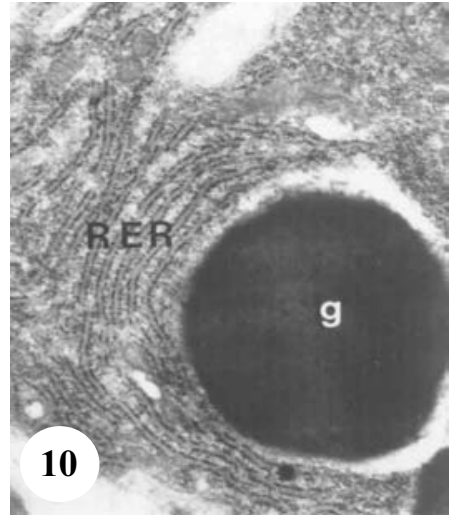

Fig. 10. Basal region of accessory gland (AG) during feeding showing a secretory granule (g) surrounded by well-developed rough endoplasmic reticulum (RER). $\mathrm{X}$ 25,500 .

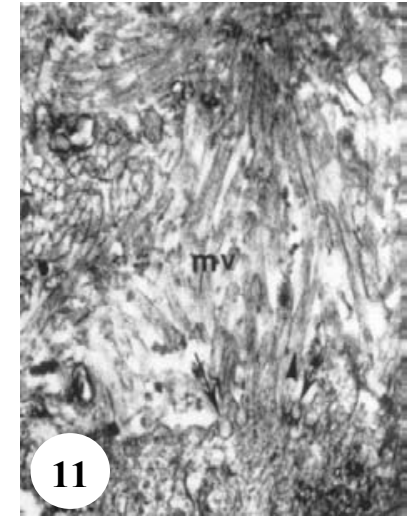

Fig. 11. As in figure 10 but showing the apical region with elongated microvilli (mv) enclosing peripheral fibrillar material (arrowheads). Note pynocytotic pits (arrows). X 40,000.

During oviposition, the pyramidal cell cytoplasm contains secretory granules of variable dense, size and structure (Fig. 13), and may represent different granular growth phases. An electron-dense material identical to that of dense granules is found in the gland lumen and closely associated to the cell apices (Fig. 14). Abundant microtubules occupy most of the cell apical regions lying perpendicular and closely attached to the heavily microvillate apical plasma membrane (Fig. 14). 


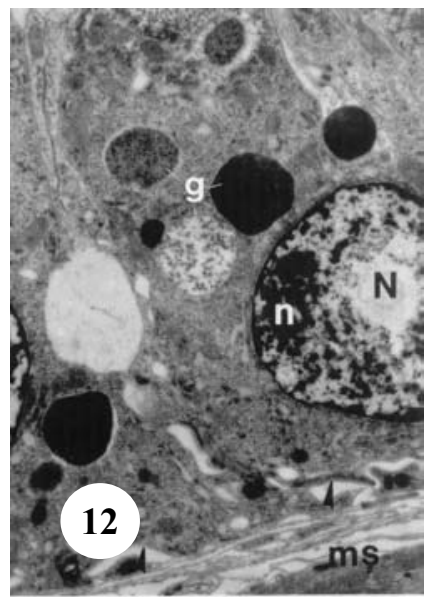

Fig. 12. Basal region of $\mathrm{AC}$ during feeding showing enlarged nuclei (N) with loose chromatin consistency and decreased dense heterochromatin seen in unfed ticks (see [7]). Note basal membrane infoldings (arrowheads), scattered granules (g) and muscle layer (ms). $n$, nucleolus. $X 11,000$.

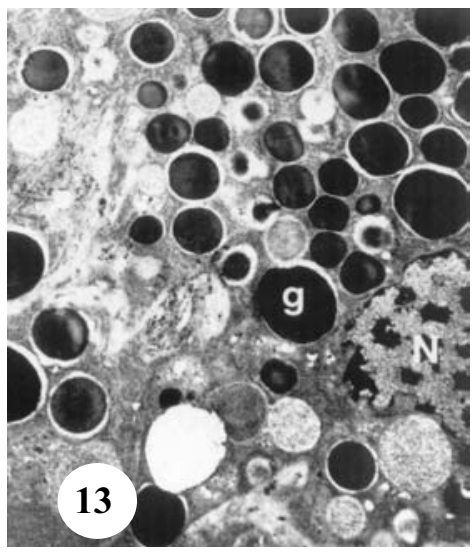

Fig. 13. AC during oviposition showing the cell cytoplasm of pyramidal containing secretory granules (g) of changeable dense, structure and size. $N$, nucleus. $X \mathbf{3 , 5 0 0}$.

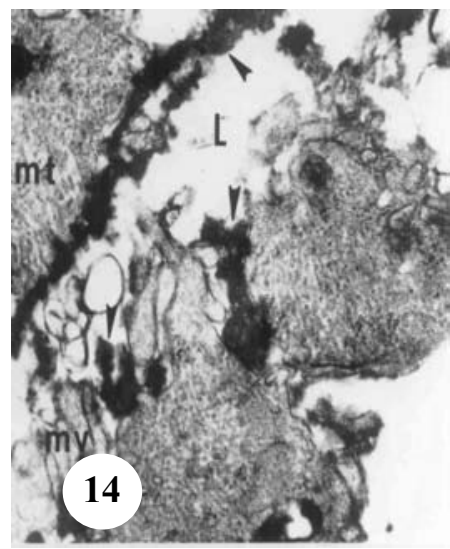

Fig. 14. AC during oviposition showing abundant microtubules (mt) in the cytoplasm of the apical region. Note dense material (arrowheads) in the lumen (L)of the gland and it seems that released through microvilli (mv). X 40,000.

\section{The Receptaculum Seminis}

Within few days of feeding and mating, and after the endospermatophores have been injected into receptaculum seminis lumen, the epithelial wall becomes greatly distended while the cuticular lining appears interrupted (Fig. 15). In advanced cells, Golgi apparatus 
giving rise to vesicles and closely associated with rough endoplasmic reticulum, in addition to free ribosomes and elongate mitochondria, are observed in the cell cytoplasm (Fig. 16). The columnar cell is filled with glycogen particles (Fig. 15\&17) characterized by their identical rosette shape, which in some areas, surround lipid-like vacuoles (Fig. 17). In middle regions of the receptaculum seminis wall, many intercellular spaces are formed by surrounding cells, the apices of which form welldeveloped microvilli (Figs. 18). These spaces are filled with a moderately dense secretion (Fig. 18\&19), and join the receptaculum seminis main lumen (Fig. 15). The irregularly outline nuclei (Fig. 19) occupy great parts of the cells. The dense granules discharge their content into the intercellular space, after fusion of their limiting membranes with microvillate apical membrane (Fig. 18\&20), and then into receptaculum seminis main lumen (Fig. 15). Coated pits and vesicles containing fine granular material, in addition to many elongate mitochondria, free ribosomes, and lysosome-like bodies are detected in the cell apical regions (Fig. 21). Lateral cell membranes are joined by long, septate junctions (Fig. 18).

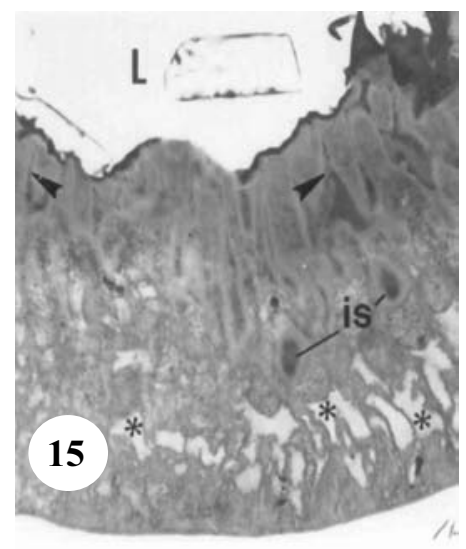

Fig. 15. Semithin section through receptaculum seminis (RS)during feeding showing narrow channels (arrowheads) communicating intercellular spaces (is) and main lumen $(L)$. Note variable size of vacuoles glycogen which was filled it, but it seems washed out during tissue processing. Note the point of interrupted cuticle (arrows). X 1,200.

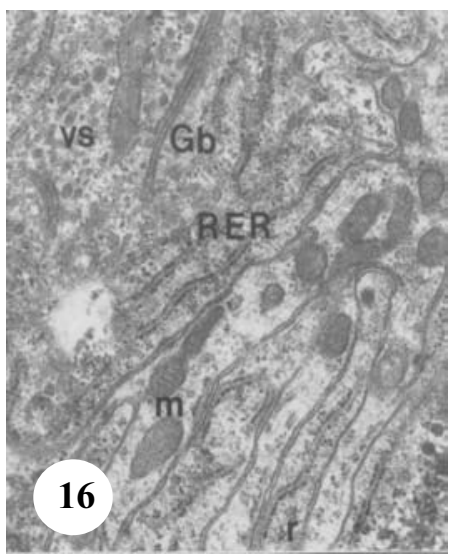

Fig. 16. Advanced RS cells during feeding showing Golgi bodies (Gb) giving rise to small vesicles (vs) and free ribosomes (r). X 25,000. 


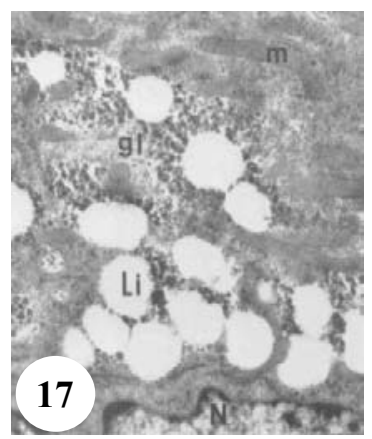

Fig. 17. Ultrathin section in RS showing lipid-like vacuoles (Li) surrounded by glycogen particles (gl). Note $\mathrm{m}$, mitochondria; $\mathbf{N}$, nucleus. X 15,000.



Fig. 19. Middle region of receptaculum seminis (RS) wall showing an intercellular space (is) formed by surrounding cells (Ep). Note nucleus $(\mathrm{N})$, secretory product (S). X 20,000.



Fig. 18. Apices of adjacent RS cells projecting well-developed microvilli (mv) and joined by septate junction (SJ). Note intercellular space(is). X 11,000.

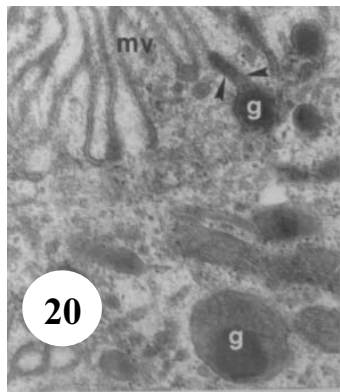

Fig. 20. Ultrathin section showing higher magnification of middle region in figure 18. Note exocytosis and granules (g) content is discharged into the intercellular space after the fusion of their limiting membranes (arrowheads) with microvilli (mv0. X 35,000.

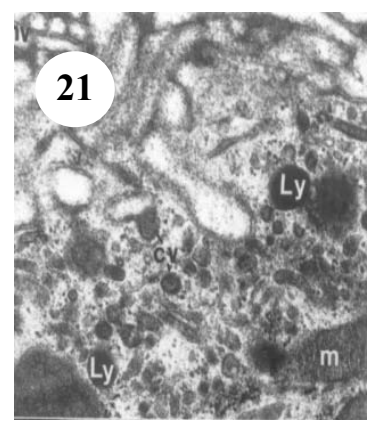

Fig. 21. Similar to figure 20 but this section showing pinocytotic vesicles (cv). Ly, lysosome-like structures; m mitochondria; mv, microvilli; r, free ribosomes. $\mathrm{X}$ 35,000 . 


\section{Oviduct}

During the attachment and feeding, epithelial cells become numerous in the entire oviduct (Fig. 22). As attachment and feeding progresses, the oviduct cells differentiate into pyramidal to columnar (Fig. 23), and the most characteristic feature of this epithelium is the penetration of their cell vacuoles by sperms (Fig. 24). The sperms are present in close association with large, membrane-limiting vacuolar structures filled with moderately dense, fine granular material (Fig. 24). The main oviduct lumen, in some regions, is divided into small, intercellular spaces by the microvillate apical cell protrusions (Fig. 25). Pinocytotic pits and vesicles (Fig. 26), rough endoplasmic reticulum (RER), elongate mitochondria, and lysosome-like structures are present in the apical regions (Fig. 27). Lateral cell membranes are joined by long desmosomes and septate junction (Figs. 25\&26), while the basal membranes form deep infoldings (Fig. 28) enclosing mitochondria, dense bodies, RER, and microtubules (Fig. 28). Many dense granules are detected in the cytoplasm, and probably discharge their content into the main duct lumen through the long, brush-border, apical microvilli (Fig. 29). The cell of the external epithelium differentiates into a layer of muscle fibres (Fig. 23), which cause peristaltic contractions of the entire oviduct during the passage of both sperms and eggs.



Fig. 22. Ultrathin section of oviduct (OV) during feeding showing the cytoplasm contain numerous cells. Note muscle layer $(\mathrm{ms})$ and the nucleus (N). X 10,000.

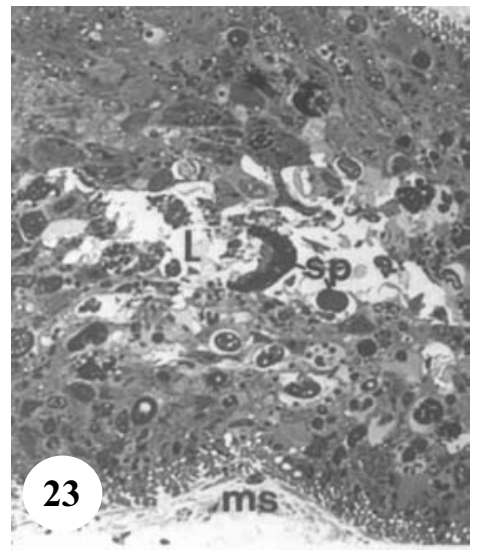

Fig. 23. Semithin section through the common oviduct (COV) showing cells invaded by sperm (sp). Note the lumen of the oviduct (L) and muscle layer (ms). X 1,200. 


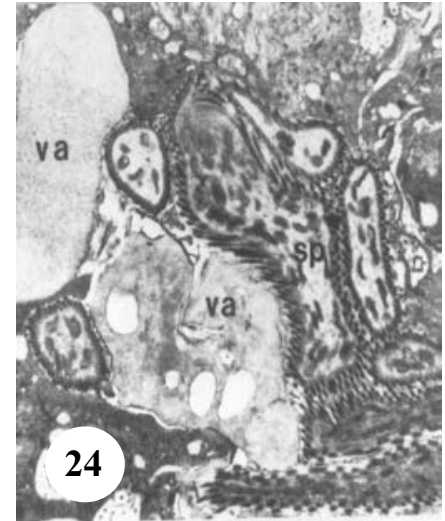

Fig. 24. Ultrathinsection through common oviduct showing vacuolar structures (va) in close association with sperms (sp). X 4,500.



Fig. 26. Oviduct cell apices containing pinocytotic pits (arrowheads) and vesicles (cv) and joined by long septate junction (SJ). Note vacuoles (va). X 25,000).

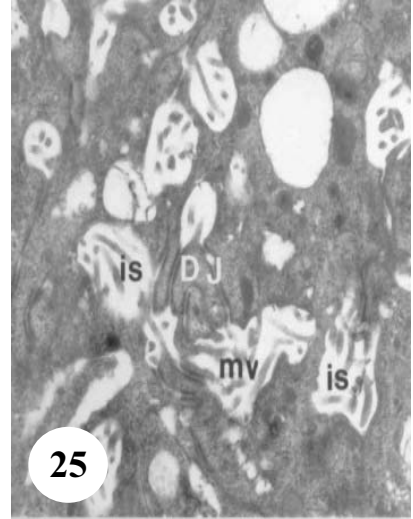

Fig. 25. Section of the main lumen of the oviduct subdivided into smaller intercellular spaces (is) by microvillate (mv) cell apical protrusions. Note septate junction of desmosome (DJ). X 15,000.

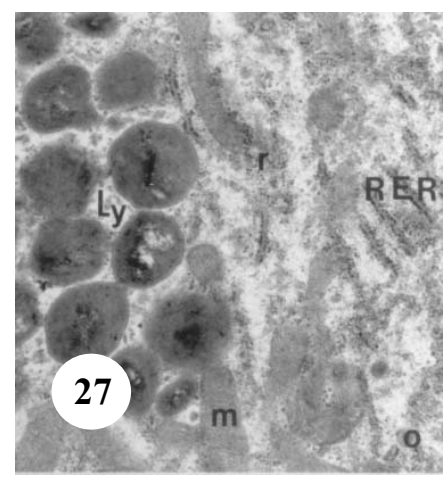

Fig. 27. Oviduct cell apices showing rough endoplasmic reticulum (RER), free ribosomes (r), mitochondri (m) and lysosome-like structure (Ly). X 20,000 .

\section{The Connecting Tube}

The epithelial cells of connecting tube are elongated and project a few, short microvilli beneath the thin cuticular lining. No sign of secretory activity has appeared in their cytoplasm during or after feeding. However, numerous rickettsia-like microorganisms are present in the cytoplasm (Fig. 30). The nuclei are present and occupy different levels in the connecting tube wall (Fig. 30). 


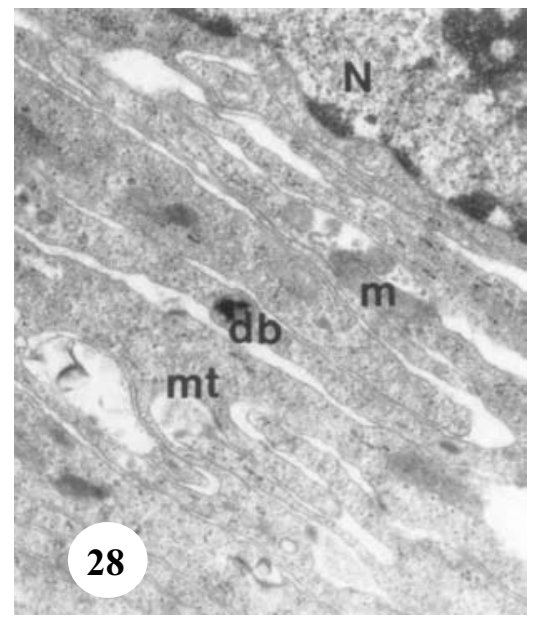

Fig. 28. Cell basal region of oviduct showing basal membrane infoldings enclosing mitochondria (m), dense bodies (db), RER and microtubules (mt). X 22, 500.

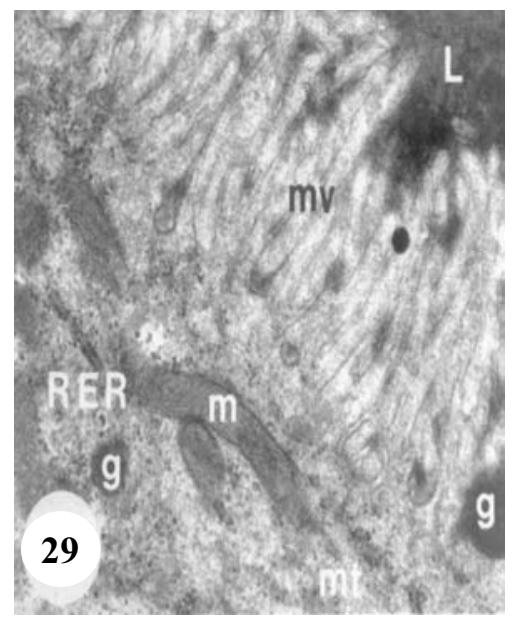

Fig. 29. Cell apical region of the oviduct during oviposition showing dense granules (g) and brush-border microvilli (mv). Note the lumen (L); mitochondria (m); microtubules (mt) and rough endoplasmic reticulum (RER). $X$ 25,000.

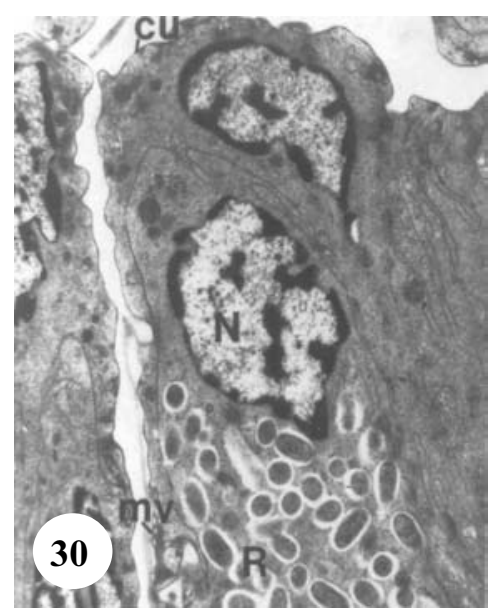

Fig. 30. Ultrathin section of connecting tube at final stages of feeding showing enlarged epithelial cells projecting a few microviili $(\mathrm{mv})$ beneath the thin cuticular lining (cu). Rickettsia-like microorganisms $(R)$ are present in close association to nucleus (n), note the lumen (L). X 11,000. 


\section{Disussion}

\section{The ovary}

The structure of the ovary appears similar to that of other ixodid and argasid ticks at the electron microscope level. In the present study, the ovarian wall of the unfed female consists of interstitial cells, dark oogonia and young oocytes. These three components have been described also in H. Asiaticum ${ }^{[13]}$, H. Dromedrii $^{[23]}$ and H .anatolicm $^{[7]}$.

Oogenesis has been described in the ixodid tick, Rhipicephalus bursa $^{[25]}$, Dermacentor andersoni ${ }^{[11]}$, Hyalomma asiaticum ${ }^{[14]}$ and Amblyomma hebraeum ${ }^{[10 \& 12]}$ and in less detail in the argasid Ornithodoros moubata ${ }^{[6,10]}$. The general pattern is the same in each of these species. Balashov ${ }^{[1,13]}$ has identified five stages of oocyte development. Stage $I$ is the oogonial development in immature stages leading to the formation of young oocytes in newly moulted, unfed females; this is a stage of "small cytoplasmic growth" [13]. Stage II is the period of "great cytoplasmic growth" of the oocyte initiated by the adult blood meal. This stage is the beginning of active enlargement of the nucleus and nucleolus, and formation of microvilli on the surface of the oocytes. The cytoplasmic organelles undergo intense development in this growth phase; the nucleus enlarges and the nuclear envelope is welldefined. The nucleoplasm contains fine granular or fibrillar euchromatin material and the nucleolus despatches dense ribosomal like granules into the nucleoplasm. The oocyte cytoplasm is rich in free ribosomes; some mitochondria and numerous rickettsia-like microorganisms. In this stage the oocyte cell membrane forms microvillar projections over the whole surface. Stage III begins with the primary yolk granule formation. In stage IV, these granules are much enlarged and increased in number. Their full development marks the end of stage IV, when they fill the oocyte cytoplasm. Stage V represents the ovulated mature egg in the ovarian lumen, oviduct and uterus. Stage II is also referred to as previtellogenic development, and stages III and IV are the vitellogenic development of oocytes ${ }^{[14]}$.

Knowledge of oocyte development in ticks is essential to the understanding of the biomedical and epidemiological importance of vector potential, and the capability for transovarial transmission of several human and animal diseases agents to their progeny. 
During feeding and attachment, the ovary increases in size, and becomes folded along its length. This increase in size has been described in the argasid ticks Argas persicus ${ }^{[12]}$ and Argas arboreus ${ }^{[26]}$, Argas arboreus ${ }^{[8]}$, and the fold has been described in the ixodid ticks $R$. Appendiculatus $^{[27]}, D$. Andersoni ${ }^{[5 \text { and } 11]}$, and $H$. Asiaticum ${ }^{[1,13]}$. In $H$. dromedarii and the other species studied, this increase in size is associated with the onset of oogenesis. In D. Andersoni ${ }^{[5,11]}$, the oocytes in the longitudinal fold are considerably smaller than those outside it. In $H$. dromedarii, oogenesis is asynchronous, so that different stages of development can be observed in the same ovary.

According to Brinton and Oliver ${ }^{[5,11]}$, this asynchronous development is probably due to the feeding processes, thus the ovary increases greatly in size and becomes folded. The oocytes outside the longitudinal fold are more active, than those in the longitudinal fold. However, Brinton and Oliver ${ }^{[5,11]}$ reported that asynchronous development is due to inhibitory effects of oocyte crowding in the longitudinal folds. This asynchronous development occurs also in $R$. Appendiculatus $^{[27]}, \quad H$. anatolicum ${ }^{[4]} ; \quad D$. Andersoni $^{[5,11]}$ and $H$. asiaticum $^{[1,13]}$.

The formation of the funicle cells in the ovarian epithelium of $H$. anatolicumi marks the beginning of the cytoplasmic growth phase (Stage II) of Balashov $[1,13]$ and $[14]$. They are a feature also in other ixodids and argasids ticks ${ }^{[6,10]}$. These connecting (funicle) cells proliferate, become columnar and, with the oocytes, extend into the body cavity carrying their connective tissue before them. Some authors have suggested that funicle cells may be a source of heterosynthetic yolk protein ${ }^{[6]}$. Others have considered that the funicle serves only to attach the oocyte to the ovarian wall ${ }^{[5,9,11]}$.

Coated vesicles similar to those seen in the funicle cells of $H$. anatolicum during feeding and attachment animals have been described in the funicle of the ixodid Rhipicephalus bursa ${ }^{[10]}$ and the argasid tick Ornithodoros moubata ${ }^{[6]}$. Balashov ${ }^{[13]}$ suggested that these vesicles may participate in the passage of high molecular substance. Their presence does suggest that the funicle cells may have more than simply a support function.

The mature sperms seen in the ovarian lumen of $H$. anatolicum presumably passed through the oviduct. Sperms have also been seen in 
the ovarian lumen of Dermacentor andersoni ${ }^{[16]}$. These mature sperms probably penetrate the epithelial funicle cells, which are probably a passage way for spermatozoa to gain access to impregnate the oocyte permitting transfer of spermatozoal nuclei into the oocytes.

The period of great cytoplasmic growth following the tick blood meal includes dramatic changes in the oocytes organelles. The oocyte is clearly entering a phase of active protein synthesis. The emission of dense granular material from the nucleolus, and its passage to the cytoplasm becomes apparent in this stage. The histochemical studies on the developing oocytes of some tick species have demonstrated the presence of basophilic granular material, interprated as ribonucleoproteins in the nucleus and perinuclear cytoplasm ${ }^{12,14]}$. Diehl et al. ${ }^{[14]}$ interprets these granules to be ribosomal precursor gaining access to the cytoplasm through nuclear pores. This interpretation is supported by the observation on $H$. anatolicum Golgi bodies in the form of scattered dictyosomes associated with dense vesicles which fuse to the ribosomal aggregates. In present paper the electron dense stacked cisternae and the vesicles derived from the Golgi complex are probably involved in the production of multivesiculate bodies. Brinton and Oliver $^{[11]}$, suggested morphogenetic mitochondrial changes in $D$. andersoni are involved in the production of membrane-limited multivesiculate bodies. In $H$. anatolicum such mitochondrial changes have not been seen. Moreover, in the present study both the ribosomal aggregates and the multivesculate bodies are associated with the formation of primary yolk granules which consist mainly of proteins. These are similar to that in Ornithodoros moubata ${ }^{[9]} ;$ D. andersoni ${ }^{[12]} H$. Asiaticum $^{[13]}$ and in some ixodids and argasids ticks ${ }^{[14]}$. According to these authors, the granular ribosomal aggregates, the small vesicles and multivesculate bodies present in $H$. anatolicum oocyte cytoplasm are all involved in the formation of the yolk granules. The involvement of mitochondria, Golgi vesicles, nucleolar emission and ribosomes in the formation of primary yolk bodies has been reported for several insect and arachnid oocytes ${ }^{[13]}$. In insects, follicle cells are involved in the formation of yolk granules ${ }^{[28]}$ and facilitate the transmission of yolk precursors from the haemolymph. In the ixodid Haemaphsalis spinigera ${ }^{[29]}$ found that the yolk bodies in the oocytes were tyrosine-rich basic proteins linked to carbohydrates. However, the histochemical ${ }^{[9]}$ and biochemical $^{[30]}$ investigations have demonstrated that the egg yolk 
proteins in several species of ixodids and argasids are haemo-glycolipoproteins. Yolk formation in tick oocytes is affected by both intraoocytic and extraoocytic synthesis ${ }^{[6,13,14]}$. Intraoocytic synthesis is concerned with activities of the cell organelles, as mentioned above. Extraoocytic synthesis is concerned with the formation of the oocyte surface.

In $H$. anatolicum the oocyte surface develops microvilli. A similar appearance of the small microvilli underlying the tunica propria in the early stages of oogenesis has been described in Dermacentor andersoni ${ }^{[5,11]}$ and $H$. asiaticum ${ }^{[13]}$. These surface microvilli in the growing oocytes may facilitate micropinocytosis of nutrient material from the haemolymph, which can penetrate through the basal lamina investing the ovarian epithelial cells. The appearance of micropinocytotic pits and vesicles in the ovarian epithelial cell cytoplasm, as well as the presence of micropinocytotic pits, vesicles, and tubes in the oocyte peripheral cytoplasm of both $H$. anatolicum and other ticks species ${ }^{[13+14]}$, supports an extraoocyte source of yolk material which is internalized into the oocyte. The fusion and condensation of such vesicles and reservoirs could form membrane-limited, finely granular bodies ${ }^{[14]}$ seen in $H$. anatolicum and other ticks. It seems likely that these fuse to the primary yolk bodies, thus forming the large yolk spheres which gradually fill up most of the oocyte cytoplasm. Future studies are needed to increase our knowledge about the full story of the oogenesis and the formation of the egg shell.

\section{Vagina}

The structure of the vestibular vagina of $H$. anatolicum is basically similar to that of $H$. asiaticum $^{[17]}$. In some ixodids the epithelium of the vestibular vagina during feeding detaches from the cuticle and becomes glandular. However, during oviposition, the lipid-rich secretion is discharged, through the cuticle, into the lumen of the gland and onto the surface of the passing egg which becomes partially waterproof ${ }^{[31]}$. Such a vestibular epithelial gland has not been observed during the feeding and mating in $H$. anatolicum. Furthermore, except for Ixodes species, the cervix in $H$. anatolicum is structurally similar to those observed for other ixodids ${ }^{[1,17,27]}$, they have a separate receptaculum seminis opening into the cervical vagina. In Ixodes ricinus ${ }^{[12]}$ and $H$. dromedarii ${ }^{[32]}$, a common oviduct acting as a receptaculum seminis opens via a short 
connecting tube into the dorsal surface of the cervical vagina. As in other tick species, the cervical vagina in $H$. anatolicum is surrounded by several, well-developed muscle layers which probably facilitate the passage of endospermatophores containing sperms into the receptaculuim seminis, and ova to the exterior. Recent research recorded that in some feeding ixodids the epithelium of the vestibular vagina detaches from the cuticle and becomes glandular. Moreover, during oviposition, the lipidrich secretion is discharged, through the cuticle, into the lumen of the gland and onto the surface of the passing egg which becomes partially waterproofed $^{[15]}$.

\section{Tubular Accessory Glands}

The accessory glands in $H$. anatolicum have synthesised their secretory granules only after attachment to the host, during feeding and mating, while in other argasids ticks ${ }^{[18,33]}$, the glands already contain secretory granules before feeding. This may be due to the remarkable behavioural differences between the two species. In $H$. asiaticum, histochemical studies have shown that these glands secrete a colloidal material containing basic proteins ${ }^{[1]}$, which presumably coats the egg surface during its passage through the cuticular vagina. The presence of microtubules in the present study is similar to that reported in $H$. asiaticum $^{[1]}$. These microtubules are probably involved in a mechanical role responsible for discharging the granular content into the gland lumen.

\section{The Receptaculum Seminis}

The receptaculum seminis is present only in ixodid ticks, and develops only during feeding and mating. Although, the fine structure and development of this organ in $H$. anatolicum is similar to that in $H$. adromedrii $^{[23]}$, but is entirely different from that of $H$. asiaticum ${ }^{[17]}$. The intercellular spaces which collect secretory products from surrounding cells and passing them, through narrow channels, into the main lumen of the organ, where the endospermatophores are present, may function as pooling systems; these probably serve to protect the microvillate cell apices from the direct contact with the endospermatophores and probably to control the flow of the cell secretion into the main lumen through the narrow channels. Enormous microvilli and infoldings basal membrane observed in receptaculum seminis cells may be characteristic features of transporting epithelia ${ }^{[34]}$. Although final stage of sperm maturation, 
spermiogenesis $^{[35]}$, present in the female genital system ${ }^{[26,36]}$, sperm should be released after the digestion of endospermatophore wall, probably by the secretion of the receptaculum seminis. The presence of the rough endoplasmic reticulum and Golgi bodies in the present paper are apparently involved in the formation of the secretion of receptaculum seminis. Moreover, the lysosome-like structures found in the cell apices may also play an important role in dissolving the wall of endospermatophore, and / or function in the break down of material taken up by pinocytosis.

The material of endospermatophric consisting of mucoproteins (Tatchell ${ }^{[37]}$ ), and other material taken up pinocytosis could undergo interacellular enzymatic digestion following rupture of these lysosomallike shape. Exocytosis and endocytosis require an energy consumption which is probably supplied by the great amount of glycogen and lipidlike vacuoles seen in the cell cytoplasm during attachment. In the argasid O.erraticus $^{[33]}$, the endospermatophore wall was broken down and sperm were released into the uterus and oviducts a few hours after 18-72 min feeding period and copulation (El-Shoura ${ }^{[37]}$ ). Moreover, the $O$. erraticus uterine secretion was thought to contain substances also involved in dissolving the endospermatophore wall. However, the recepataculum seminis in $H$. anatolticum must look forward for further histochemical investigations to make known its chemical nature.

\section{The Connecting Tube}

It seems no remarkable cellular activity was recorded in this organ during feeding and copulation. However, only the changes were for the expansion of the deep folds of connecting tube during oviposition. Moreover, contact of the cuticular lining with underlying cells, and microtubules associated with desmosome-like structures probably provide strong mechanical support for the wall of the connecting tube during oogenesis or egg passage. Also during oviposition, the cuticular folds disappear as the eggs pass by.

\section{Oviducts}

The paired oviducts in $H$. anatolicum combine distally to form a common oviduct. This is similar to that described in ixodid $D$. Andersoni $^{[16]}$, H. Asiaticum ${ }^{[17]}, H$. dromedrii ${ }^{[32]}$. and H. Anatolicum ${ }^{[7]}$. The penetration of the sperm to the oviduct cell vacuoles is a 
phenomenon which has been recorded for other ixodids ${ }^{[16,27]}$ and argasids ${ }^{[14,18,33]}$. These vacuoles are considered to be phagolysosmes which, for unkown reason, are thought to play a role in breaking down some of the sperms ascending to the ovarian lumen. Oviducal epithelial cells respond to intercellular invasion by sperms in a clearly defensive manner. Formation of vacuolar structures, or capsules ${ }^{[16]}$, apparently serves to inhibit continued intracellular movement of giving sperm cells, thus preventing further disruption of interacellular organization. The vacuolar structure then becomes a protective barrier for the host cell, increasing its chance to maintain integrity of the epithelium as suggested by Brinton et $a l^{[16]}$.

The presence of lysosomal-structures in the cell cytoplasm of the oviduct they probably play a function in the breakdown of seminal fluid or other material taken up by pinoctosis during sperm passing into the lumen of the oviduct. Moreover, the dense granular secretion detected in the cell cytoplasm of the oviduct in $H$. anatolicum has been described for D. Andersoni ${ }^{[16]}$; their contents suggest to act as tanning agents to sclerotize the soft cuticle of the egg shell, and also possibly serving as a lubricant for egg passage ${ }^{[29]}$. However, during oviposition, the membrane infoldings dramatically increase in number and height, becoming perpendicular to the surrounding basal lamina. This kind of structure may also assist for egg passage after the oviposition.

\section{Acknowledgment}

I express my appreciation to Professor Dr. Sayed Fahim, Department of Biology, Teacher college, Makkah, for his support and encouragement.

\section{References}

[1] Balashov, Yu.S., Bloodsucking Ticks (Ixodoidea - Vectors of Diseases of Man and Animals). Zoo I. Inst., USSR Acad. Sc. Nauka, Leningrad (1968) (in Russian; English translation by Entomological Society of America), 319 pp (1972).

[2] Hoogstraal, H., Wassef, H.Y. and Buttiker, W., Ticks (Acarina) of Saudi Arabia, Fam. Argasidae, Ixodidae. In: W. Wittmer and W. Buttiker (Editors), Fauna of Saudi Arabia, Basel, 3: 25-110 (1981).

[3] Burgdorfer, W. and Varma, G.R., Transstadial and trans ovarial development of disease agents in arthropods. Annu. Rev. Entomol., Entomol. 12: 347-376 (1967).

[4] Khalil, G. Biochemical and physiological studies of certain ticks (Ixodoidea). Gonad development and gametogenesis in Hyalomma $(\mathrm{H})$. anatolicum excavatum Koch (Ixodidae). J. Parasit 56: 596-610 (1970). 
[5] Brinton, L.P. and Oliver, J., Gross anatomical, Histological and cytological aspects of ovarian development in Dermacentor andersoni Stiles (Acari-Ixodidae). J. Parasit. 57: 708 719 (1971a).

[6] Aeschlimann, A. and Hecker, H., Observations preliminairs sur I ' ultrastructure de I' ovocyte en development chezt Ornithodorus moubat, Murray (Ixodoidea: Argasidae). Acta Trop 24: 225-243 (1967).

[7] Bughdadi, F.A., Ultrastructural Study On The Genital System in Female Tick Hyalomma (Hyalomma) Anatlicum Anatolicum (Ixodoidea: Ixodidae). In press (2009).

[8] Khalil, G., Biochemical and physiological studies of certain ticks (Ixodoidea). Gonad development and gametogenesis in Argas (Persicargas) arboreus Kaiser, Hoogstraal and Kohls (Argasidae). J Parasit 55: 1278-1297 (1969).

[9] Diehl, P.A., Zur Oogenese bei Ornithodoros moubata Murray (Ixodoidea: Argasidae) unter besonderer Berucksichtigung der Vitellogenese. Acta Trop. 27: 301-355 (1970).

[10] Aeschilmann, A. and Hecker, H., Presence de membrane annulees dans les ovocytes d' Ornithodoros moubata Murray (Ixodoidea: Argasidae). Acta Trop. 27: 268-270 (1970).

[11] Brinton, L.P. and Oliver, J., Fine structure of oogonia and oocyte development in Dermacentor andersoni Stiles (Acari-Ixodidae). J. Parasit. 57: 720-747 (1971b).

[12] Roshdy, M.A., Structure of the female reproductive system of Ixodes ricinus (L.) and its bearing on the affinity of Ixodes to other ixodid genera. J. Parasitol., 55: 1078-1083 (1967).

[13] Balashov, Yu. S., An atlas of ixodid tick ultrastructure. Zoolinst, USSR AKAD Science, Nauka Publ, Leningrad (1979). (In Russian) (English translation: Special Publication Entomol Soc Am p 1-289) (1983).

[14] Diehl, P.A., Aeschlimann, A. and Obenchain, F.D., Tick reproduction: Oogenesis and oviposition. In: F.D. Obenchain and R. Galun (Editors), Physiology of Ticks. Pergamon Press, Oxford, pp. 277-350 (1982).

[15] Julian, A., Patricia, R., Gervasia, H.B. and Maria, I., Ultrastructural detection of proteins, lipids and carbohydrates in oocytes of Amblyomma triste (Koch, 1984) (Acari ; Ixodidae) during the vitellogenesis process. Dept of biology, I. B., UNESP, AV. 24 A. no 1515. Cx postal 199, CEP 13506-900 Rio clro-sp, Brazil (2007).

[16] Brinton, L.P., Burgdorfer, W. and Oliver, J.H., Histology and fine structure of spermatozoa and egg passage in the female tract of Dermacentor andersoni Stiles (Acari: Ixodidae). Tissue Cell, 6: 109-125 (1974).

[17] Raikhel, A.S., Female reproductive system. In: Yu.S. Balashov (Editor), An Atlas of Ixodid Tick Ultrastructure. Entomol. Soc. Am. Spec. Publ., pp. 212-277 (1983).

[18] El Shoura, S.M., Fine structure of the vagina, accessory glands, uterus, oviducts and Gene's organ in the unfed tick, Ornithodoros (Pavlovskyella) erraticus (Ixodoidea: Argasidae). Exp.Appl. Acarol., 4: 95-108 (1987b).

[19] El Shoura, S.M., Fine structure of the Gene's organ in the Camel tick Hyalomma (Hyalomma) dromedrii (Ixodoidea: Ixodidae). J. Morphol., 193: 91-98 (1987c).

[20] EI Shoura, S.M., Hoogstraal, H. and Roshdy, M.A., Nuttaliella namaqua (Ixodoidea: Nuttalliellidae): female internal morphology. J. Parasitol., 70: 114-120 (1984).

[21] Burger, M., Peter, M., Werner, Graber. Alain, J. Wolfgang, N. and Christian, K., Complex genital system of a haplogyne spider (Arachnida, Araneae, Tetrablemmidae) indicates internal fertilization and full female control over transferred sperm. J. Morphol., 276: 116-186 (2005).

[22] Spurr, A.R., A low viscosity epoxy resin embedding for electron microscopy. J. Ultrastract. Rec. 26: 31-43 (1969).

[23] Bughdadi, F.A., Ultarastructure study on the general tract, Oogenesis and Spermiogenesis of the Camel Tick Hyalomma (Hyalomma) Dromedarii. Msc Thesis, School of Biological Science, Manchester University (1989).

[24] Brinton, L.P., Ovarian intercellular bridges in Dermacentor. 
[25] Aeschilmann, A. and Hecker, H., Presence de membrane annulees dans les ovocytes d' Ornithodoros moubata Murray (Ixodoidea: Argasidae). Acta Trop. 27: 268-270 (1970).

[26] EI Shoura, S.M., Fine structure and development of the sperm of the tick Ornithodoros (Pavlovskyella) erraticus (Ixodoidea: Argasidae). J. Morphol., 190: 63-71 (1986).

[27] Till, W.M., A contribution to the anatomy and histology of the brown tick, Rhipicephalus appendiculatus Neumann. Mem. Entomol. Soc. S. Afr., 6: 1-24 (1961).

[28] Huebner, E., Tobe, S.S. and Davey, K.G., Structural and functional dynamics of oogenesis in Glossina austeni vitellogenesis with special reference to the follicular epithelium. Tissue Cell 7: 535-558 (1975).

[29] Chinery, W.A., Studies of the various glands of the tick Haemaphysalis spinigera Neumann 1897. Acta Trop. 22: 235-266 (1965).

[30] Araman, S.F., Protein digestion and synthesis in ixodid females. In Rodriquez J.G (ed) Rec. Adv. Acarology. Vol. I Academic Press, pp. 385-395 (1979).

[31] Lees, A.D. and Beament, J.W.L., An egg-waxing organ in ticks. Q1. J. Microsc. Sci. 89: 29332 (1948).

[32] El Shoura, S.M., Effect of blood meal and mating on the genital tract ultrastructure in the female Hyalomma (Hyalomma) dromedarii (Ixodoidea: Ixodidae). Exp. Appl. Acarol. 6:157175 (1989).

[33] EI Shoura, S.M., Biological and morphological studies on the tick Ornithodoros (Pavlovskyella) erraticus Lucas (Ixodoidea: Argasidae). M.Sc. thesis, Faculty of Sciences, Ain-Shams Univ., Cairo, Egypt (1975).

[34] Berridge, M.J. and Oschman, J.L., Transporting epithelia. New York, Academic Press (1972).

[35] Oliver, J.H., Tick reproduction: Sperm development and cytogenesis. In Obenchain, F.D., Galun, R. (eds.) Pergamon Press, New York, pp. 245-276 (1982). [27]

[36] El Shoura, S.M., Spermiogenesis ultrastructure of the tick Argas (Persicargas) Arboreus (Ixodoidea: Argasidae). J. Med. Entomol., 24: 532-535 (1987a).

[37] Bughdadi, F.A., Fine structure of the nymphal integument in the Camel Tick Hyalomma (H) anatolicum anatolicum ( Ixodoidea: Ixodidae). J. of King Abdulazize University Science. 20: 193-202 (2008).

[38] Tatchell, R.J., Studies on the meal reproductive glands and the spermatophore of the tick, Argas persicus, Oken. Parasitology, 52: 133-142 (1962).

[39] EI Shoura, S.M., The life cycle of Ornithodoros (Pavlovskyella)erraticus (Ixodoidea: Argasidae) in the laboratory. J. Med. Entomol. 24: 231-236 (1987e). 


\title{
دراسة التركيب الدقيق للجهاز التتاسلي خلال التغذية والجماع على أنثى القراد هيالوما هيالوما اناتوليكوم اناتوليكوم (اكسودويدي) (اكسوديدي)
}

\author{
د. فيصل عبد القادر بغدادي \\ كلبة الدعلمين، جامعة أم القرى، مكة المكرمة \\ المدلكة العربية السعودية
}

الدستخلص: تم وصف التركيب الدقيق للجهاز التناسلي لأنثى القراد

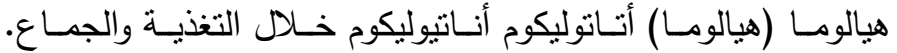
تستهل التغيرات خلال التغذية على نمو الخلية البيضية خلال مرحلة

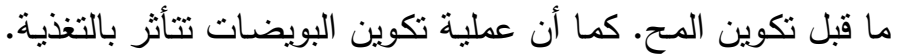
خلال نمو الخلية البيضية النامية تفرز حبييات كثيفة في السيتوبلازم تشكل الزوائد الاقيقة السطحية. السيتوبلازم يحتوي حويصلات أجسام جولجي، الثبكة الإندوبلازميـة المحيبة وأجسام حويصلية متعددة،

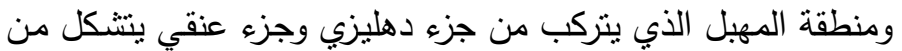
طلائية تمتد داخلياً مبطنة بواسطة طبقة من جليد ملتو وممتد، وتحاط لئل



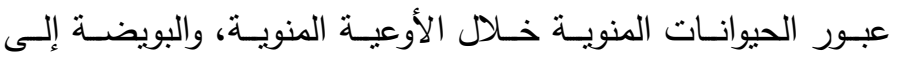



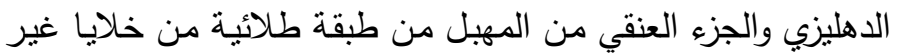
منقسمة. ونتيجة للتغذية المتقدمة تنبي هذه الخلايا الحبيبات الإفرازية،

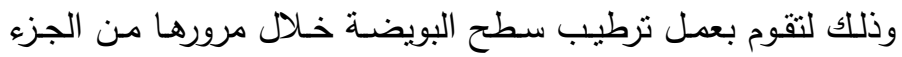

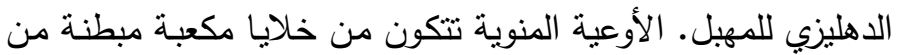


الجليد. وهذه الخلايـا تبدو غنيـة بـالجليكوجين، تجـاويف الليبيدات. والتي ربما تقوم بعمل إمداد جرعات من الطاقة التي تحتاجها الخلايا المختلفـة للنشـاط التـي تقوم بـه، خاصــة ببنـاء الحبيبـات وإخراجها الخلـوي. الحبيــات تخـرج محتوياتهـا خـلال الفتحـات البـين خلويـة، وتتنشـر خارجيًا خـلال جدار الوعاء المنوي، تتصل بالقناة الرئيسية


التغذية في الأنبوب الرابط .شوهد عند وخلال مرحلة التغذية النهائية، سيتوبلازم الخلية يحتوبي على تجاويف كبيرة، تم اختراقها بواسطة


في تكسير الحويصلات الحاملة للسوائل المنوية ومواد أخرى. إفـرازات قنـاة البيض ربمـا تعمـل كـأداة تجليـــ وتقوبـة لقتــرة البويضة، وكذلك ربما تعمل كمرطب في حالة عبور البويضة للخارج.

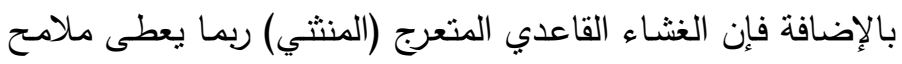
مميزة للطلائية المعنية بنقل الماء المتأين. 